PRINT ISSN 1119-8362

Electronic ISSN 1119-8362
Full-text Available Online at

https://www.ajol.info/index.php/jasem

http://ww.bioline.org.br/ja
J. Appl. Sci. Environ. Manage.

Vol. 24 (9) 1489-1494 September 2020

\title{
Comprehensive Assessment of Sanitary Landfills in Edo State of Nigeria for Waste Management and Pollution Control
}

\author{
*1 KINGSLEY-OMOYIBO, Q; ${ }^{2}$ AKHIMIEN, FO \\ ${ }^{* 1}$ Department of Mechanical Engineering; ${ }^{2}$ Department of Civil Engineering, Igbinedion University Okada, Okada Town, Edo State, \\ Nigeria \\ *Corresponding Author Email: queeneth.omoyibo@iuokada.edu.ng; Other Author Email: faith.akhimien@iuokada.edu.ng
}

\begin{abstract}
ABSRACT: The aim of this study is to comprehensively assess the need for Sanitary landfills in Edo state for management of waste, control of pollution for sustainable manufacturing system using concurrent triangulation design. The concurrent triangulation design is in two phases, Phase 1 using quantitative analysis, descriptive statistics while phase 2 used the qualitative analysis using thematic selection. Final results collected from the merger of results from phase 1 and phase 2 showed the Regression analysis results had a T-test value of -0.4615 at $P$ value significant of 0.000 obtained for Sanitary landfill in the model and was less than $5 \%$ level of significance indicating that there is a significant relationship between Sanitary landfilling and pollution control. The Durbin Watson result of 1.955 showed that the model is reliable with absence of serial auto correlation. A coefficient of -0.346 showed that $1 \%$ increase in sanitary landfilling activities results in $34.6 \%$ decrease in environmental pollution. Hence Sanitary landfilling for waste management has proved to sustain manufacturing system, control environmental pollution and reduce waste.
\end{abstract}

\section{DOI: https://dx.doi.org/10.4314/jasem.v24i9.1}

Copyright: Copyright (C) 2020 Kingsley-Omoyibo and Akhimien. This is an open access article distributed under the Creative Commons Attribution License (CCL), which permits unrestricted use, distribution, and reproduction in any medium, provided the original work is properly cited.

Dates: Received: 01 August 2020; Revised: 27 August 2020; Accepted: 20 September 2020

Keywords: Sanitary landfilling, waste management, pollution control, sustainable manufacturing system,

Sanitary landfills are sites used for disposing municipal solid waste. It is a large expanse of land acquired by government where engineering systems are put in place to help manage surface water, contain municipal waste and safety in the sanitary landfill is regulated by regulators (Seo et al, 2004). Once a Sanitary landfill is dogged, it is lined with plastics that are synthetic in order to prevent surface water contamination (Holze, 2019). Specialized pipes are inserted into the ground to drain off bad smell and methane gas is collected (Orebiyi, 2010). Waste are dumped into the large pit and compressed properly with layers of clay soil and topsoil to prevent exposure and the Sanitary land fill, the ground water, surface water and leachate are monitored (Egun, 2010).

Everyday waste dumped into the Sanitary landfill mixes with water. It decomposes and forms leachate. Gas is produced in the form of methane gas and sent into the air (Fei et al, 2019). Sanitary landfill gasmethane is compressed, sent into air cooler and then sent into a second filtering chamber before being reheated and packaged to use for generating electricity (UNEP, 2002). Waste disposal that support sustainable manufacturing systems such as Recycle, Reuse, Reduce, Remanufacture and use of sanitary landfills (Senkoro, 2013) which are sustainable manufacturing waste disposal methods that use economical processes to conserve waste and protect the environment (Mohammed et al 2012). Activities associated with all manufacturing processes produce waste called industrial waste and pollutes the environment which causes environmental pollution (Abu Rukal, et al 2010). Industrial waste produce noxious gases such as hydrocarbon, organo-sulpur, Carbon (II) Oxide, Nitrogen $\left(\mathrm{N}_{2}\right)$, Alcohol and greenhouse gases (Costa, 2019). Sanitary landfills produces heavy metals that pollute the land, water, air and also produce hazardous waste which cannot be disposed into sanitary landfills (Awomeso, et al 2010). Operations in Sanitary landfills reduce waste gas to methane gas and in order to control pollution, the methane gas is trapped, collected, purified and used for energy generation (Magdalena, 2019). Daily waste collected at sanitary landfills, are covered by topsoil to prevent air pollution as smell from water mixing the waste, produces foul smell. Leachates toxins affect underground water, so Pipes are run into the underground to prevent underground water pollution (Robertson, 2019). Sanitary landfill is monitored and controlled by environmentalist, and this ensures that Goals number 7 of the sustainable development goal (SDG) which is Affordable and clean energy access will be met practicing the use of sanitary landfill for sustainable manufacturing waste disposal method (Adewale, 2011). Sanitary landfilling as a sustainable manufacturing waste disposal method have suffered 
setbacks such as, not having third party experts to monitor the ground water for positive environmental impact. Conserving water and preventing water pollution is also a setback. Majority of Sanitary landfills are built and operated at low standards. The Gas (sanitary landfill Gas) produced are underutilized. There is a low level of awareness about the importance of establishing sanitary landfills. Hence; more sanitary landfills should be built for people to embrace sanitary land fill practices in order to achieve the following specific objectives:

To comprehensively assess sanitary landfills in Edo state in order to effectively manage waste and control pollution. This objective was pursued using the concurrent triangulation design.

\section{MATERIALD AND METHODS}

Methodology: The concurrent triangulation model was used in this study. The model used both quantitative and qualitative analysis. The quantitative analysis used closed ended questions using questionnaires survey and descriptive statistics. The qualitative analysis used the in-depth interview method with thematic analysis. Regression analysis was used to validate the results obtained. The concurrent triangulation design is presented in figure1.

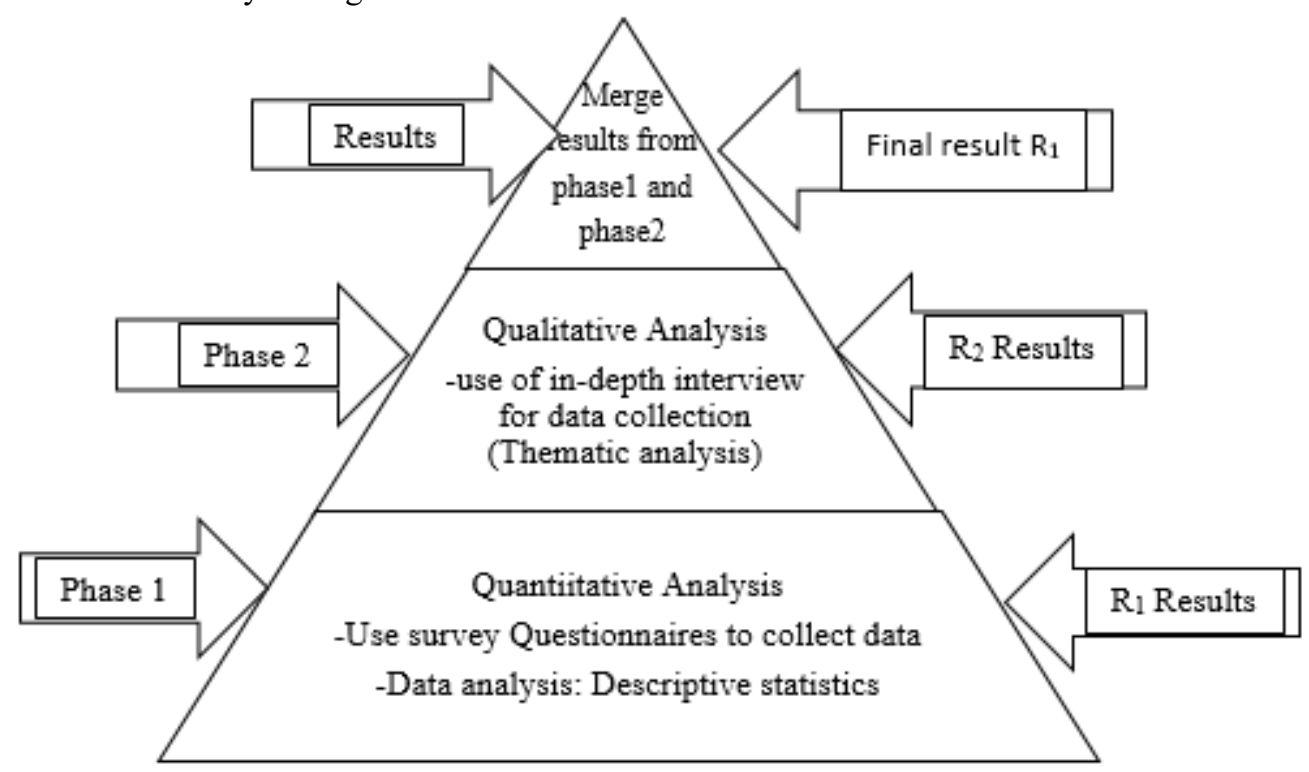

Fig 1: Concurrent triangulation model (source of figure design: Kingsley-Omoyibo, Queeneth, 2020)

The electronic mail system (e-mail) generated using a dedicated account, using a professional email address and uploading a list of recipients imported from a CSV file, was used to distribute two hundred (200) close ended questions in questionnaires and a total of one hundred and fifty six (156) were found useable. For the second phase, the qualitative analysis was carried out using in-depth interview with a sample size of fifty (50) people. Only thirty (30) in-depth interviews conducted were found useable for the analysis.

A total of one hundred and eighty six (186) responses were analyzed and recorded. Residual statistics was used to validate the model. Sanitary landfilling as a waste disposal method was introduced to the sample size as a waste management system.

Soil scientist, chemist, environmental waste disposal officers, manufacturers and individuals were given questionnaires and interviewed in-depth and results were collected, analysis, merged and recorded.

\section{RESULTS AND DISCUSSIONS}

Table 1 recorded responses for both the questionnaires and in-depth interview and a total of seventy-two (72) respondents were of the view that more sanitary landfills should be built, operated at high standards to increase the level of awareness for sanitary landfills, monitor ground water and control air, water and land pollution in order to sustain manufacturing systems. The highest response at $38.71 \%$ was recorded for employees of the manufacturing sector who were of the opinion that encouraging the use of sanitary landfills as waste disposal method will help to sustain manufacturing systems and curb environmental pollution. 39 Individuals responded at $20.97 \%, 35$ environmental waste managers at $18.82 \%, 20$ chemists and soil scientists recorded $10.75 \%$ each. Table 2 showed the responses from the Questionnaires only. From the useable questionnaires distributed, the industrial sector made up of manufacturers with 60 responses at $38.5 \%$ with the highest responses were of the opinion that more sanitary landfills should be built, 
monitored and controlled in order to sustain manufacturing systems. The least response was from chemists who were of the opinion that ground water pollution should be addressed even when they supported sanitary landfills as ideal waste disposal method. 33 environmental waste managers were of the support for sustenance of sanitary landfill with $21.2 \%$ and individuals at $19.2 \%$ response with 30 respondents supported the sustenance of sanitary landfills. From the questionnaires, the manufacturing sector was in full support of the establishment of sanitary landfills. An in-depth interview was carried out on the assessment of landfills as an ideal waste disposal method for sustainable manufacturing systems. From 30 interviews, 12 respondents at $40 \%$, were of the opinion that sanitary landfill waste disposal method when operated under standard conditions, will help to protect the environment, control pollution for sustainable manufacturing systems as shown in Table 3. From Table $3,30 \%$ of the responses were from individuals with 9 respondents assessing sanitary landfill waste disposal as the method of waste disposal that will help to reduce waste, control pollution and sustain manufacturing systems. No responses were recorded for soil scientists.7 chemistry experts at $23.3 \%$ were recorded while two only 2 environmental waste managers interviewed had a record of $6.7 \%$, with the least response. A total of 72 respondents at $38.71 \%$ response from the industry sector agreed that sanitary landfill will help curb pollution, generate energy and also generate compost for agricultural production. Showing that the manufacturing sector fully supported the establishment of more sanitary landfills for industrial waste disposal.

Table 1: Questionnaires and in-depth interview found useable for sanitary landfills in Ora village (Ovia North East local Government Area) Edo State.

\begin{tabular}{llll}
\hline S/N & Stakeholders in sanitary landfilling & Respondents & Percentage (\%) \\
\hline 1. & Soil scientist & 20 & 10.75 \\
2. & Chemist & 20 & 10.75 \\
3. & Environmental waste managers & 35 & 18.82 \\
4. & Manufacturers & 72 & 38.71 \\
5. & Individuals & 39 & 20.97 \\
& Total & 186 & $100 \%$ \\
\hline
\end{tabular}

Table 2: Responses from the Questionnaires distributed.

\begin{tabular}{llll}
\hline S/N & Stakeholder in sanitary landfilling & Respondents & Percentage (\%) \\
\hline 1. & Soil scientists & 20 & 12.8 \\
2. & Chemist & 13 & 8.3 \\
3. & Environmental waste managers & 33 & 21.2 \\
4. & Manufactures & 60 & 38.5 \\
5. & Individuals & 30 & 19.2 \\
& Total & 156 & 100 \\
\hline
\end{tabular}

\begin{tabular}{llll}
\multicolumn{5}{c}{ Table 3: Data from the in-depth interview on assessment of sanitary landfills. } \\
\hline S/N & Stakeholders in sanitary landfilling & Respondents & Percentage (\%) \\
\hline 1 & Soil scientists & 0 & 0 \\
2 & Chemist & 7 & 23.3 \\
3 & Environmental waste managers & 2 & 6.7 \\
4 & Manufacturers & 12 & 40 \\
5 & Individuals & 9 & 30 \\
& & 30 & $100 \%$ \\
\hline
\end{tabular}

\begin{tabular}{llllllllll}
\multicolumn{10}{c}{ Table 4: Standard error of estimate } \\
\hline Model & $\mathrm{R}$ & R square & $\begin{array}{l}\text { Adjusted } \\
\text { R squared }\end{array}$ & $\begin{array}{l}\text { Standard error } \\
\text { of estimate }\end{array}$ & $\begin{array}{l}\text { R square } \\
\text { change }\end{array}$ & F value & df 1 & df 2 & $\begin{array}{l}\text { Sig F } \\
\text { change }\end{array}$ \\
\hline 1 & $0.322^{\mathrm{a}}$ & 0.806 & 0.099 & 0.65683 & 0.104 & 21.30 & 1 & 184 & 0.000 \\
\hline
\end{tabular}

Dependent variable: sanitary landfill waste disposal method. From Table 4, coefficient of determination Rsquare value of 0.104 indicated that there is a good level of prediction for sanitary landfill. It showed that the dependent variable (sanitary landfill), explained $80.6 \%$ of the variability of sanitary landfill methods and its prospects with only $10.4 \%$ not explain. The F value of 21.30 showed that the independent variables statistically and significantly predicted the dependent variable (sanitary landfill). Values of F $(1,184)=$
21.30, $\mathrm{P}>0.05$ indicated that the regression model is a good fit for the data. The Durban Watson statistics, which was recorded at 1.955 showed absence of serial auto correlation in the regression analysis and also showed that the model can be relied upon.

Hypothesis Testing: In respect to the results recorded in the regression analysis conducted at a 5\% level of significance, testing the hypothesis formulated was done in null form for this study. The decision rule 
showed that if $\mathrm{P}$-values (significant) were greater than $0.05(5 \%)$ level of significance, then the null hypothesis $\left(\mathrm{H}_{0}\right)$ will be accepted. But if the $\mathrm{P}$ - values (significant) are less than $0.05(5 \%)$ level of significance, we accept the alternate hypothesis $\left(\mathrm{H}_{\mathrm{A}}\right)$.

Hypothesis one: $\mathrm{H}_{1}$ : There is no significant relationship between sanitary landfills and soil scientist perceptions. The p-value for soil scientists' perceptions in the regression result is 0.00 . The pvalue is less than 0.05 . On this basis, we reject the null hypothesis $\left(\mathrm{H}_{0}\right)$ and accept the alternate hypothesis $\left(\mathrm{H}_{\mathrm{A}}\right)$ that there is significant relationship between sanitary landfill operations and soil scientists' perceptions in assessing sanitary landfills for waste management and pollution control for sustainable manufacturing systems in Ora village, Edo state.

Hypothesis two: $\mathrm{H}_{1}$ : There is no significant relationship between sanitary landfills and chemistry experts and their perceptions. The p-value for chemistry experts and their perceptions in the regression result is 0.00 . The $p$-value is less than 0.05 , on this basis, we reject the null hypothesis $\left(\mathrm{H}_{0}\right)$ and accept the alternate hypothesis $\left(\mathrm{H}_{\mathrm{A}}\right)$ that there is a significant relationship between sanitary landfill operations and perceptions of chemistry experts in assessing sanitary landfills for waste management and pollution control for sustainable manufacturing system in Ora village, Edo state.

Hypothesis three: $\mathrm{H}_{1}$ : There is no significant relationship between environmental waste management officers and operation in sanitary landfill.
The $\mathrm{p}$ - value for environmental waste managers in the regression results recorded is 0.00 . This $p$-value is less than 0.05 . On this note, we reject the null hypothesis $\left(\mathrm{H}_{0}\right)$ and accept the alternate hypothesis $\left(\mathrm{H}_{\mathrm{A}}\right)$ that: there is a significant relationship between operations of sanitary landfills and perceptions of environmental waste management officers in Ora village, Edo State.

Hypothesis four: $\mathrm{H}_{1}$ : There is no significant relationship between operations of sanitary landfills and manufacturers in the industrial sector. The p-value for manufacturers in the industrial sector in the regression result is 0.00 . Showing that the p-value is less than 0.05. Based on this, the null hypothesis is rejected $\left(\mathrm{H}_{\mathrm{o}}\right)$ and the alternate hypothesis $\left(\mathrm{H}_{\mathrm{A}}\right)$ is accepted, that there is significant relationship between perceptions of manufacturers in the industrial sector and operations of sanitary landfills in Ora village, Edo State.

Hypothesis five: $\mathrm{H}_{1}$ : There is no significant relationship between operations of sanitary landfills and individuals in the environment where sanitary landfill is sited in Ora village in Edo state. The p-value for the perceptions of individuals in the environment where sanitary landfill operations are carried out as recorded in the regression result is 0.00 . Showing that the p-value is less than 0.05 . Based on this, the null hypothesis is rejected $\left(\mathrm{H}_{0}\right)$ and the alternative hypothesis $\left(\mathrm{H}_{\mathrm{A}}\right)$ is accepted, that there is significant relationship between perceptions of individuals and operations of sanitary landfills in Ora village, Edo state.

Table 5: ANOVA for Sanitary landfilling ${ }^{a}$

\begin{tabular}{llllll}
\hline Model & Sum of square & Df & Mean Square & F & Significance \\
\hline Regression & 9.189 & 1 & 9.189 & 21.30 & $0.000^{\mathrm{a}}$ \\
residual & 19.382 & 184 & 0.431 & & \\
Total & 88.571 & 185 & & & \\
\hline
\end{tabular}

A. Dependent variable: Sanitary landfilling. B. Predictor: Soil Scientist, Chemist, Environmental Waste Management, Manufacturers and Individuals.

\begin{tabular}{|c|c|c|c|c|c|}
\hline Model & \multicolumn{2}{|c|}{$\begin{array}{l}\text { Unstandardized } \\
\text { coefficient }\end{array}$} & $\begin{array}{l}\text { Standard } \\
\text { coefficient }\end{array}$ & $\begin{array}{l}\text { Standard } \\
\text { Coefficient }\end{array}$ & \multirow[t]{2}{*}{ T Test } \\
\hline \multirow{3}{*}{ 1 Sanitary Landfilling } & \multirow{3}{*}{\multicolumn{2}{|c|}{$\begin{array}{l}\text { B } \\
2.240 \\
-0.346\end{array}$}} & Standard error & Beta & \\
\hline & & & 0.291 & -0.322 & \multirow{2}{*}{$\begin{array}{l}7.697 \\
-4.615 \\
\end{array}$} \\
\hline & & & 0.075 & & \\
\hline \multicolumn{6}{|c|}{ Table 7: Residual statistics for sanitary landfilling } \\
\hline & Minimum & Maximum & Mean & Standard deviation & $\mathrm{N}$ \\
\hline Predicted value & 2.2404 & 4.6812 & 3.5652 & 0.2228 & 186 \\
\hline Residual & -2.1752 & 4.1067 & 0.000 & 0.6550 & 186 \\
\hline Standard predicted value & -5.9440 & 5.0070 & 0.000 & 1.0000 & 186 \\
\hline Standardized residual & -3.3090 & 6.2520 & 0.000 & 0.9970 & 186 \\
\hline
\end{tabular}

Validation: Results were validated using the residual statistics. Standard errors of 0.291 and 0.075 which were relatively low/ from Table 6 , showed that the mean is relatively close to the true mean of the 186 
overall responses recorded. The margin of error (at $95 \%$ confidence) for the mean is roughly twice that value of $+/-0.145$ where the true mean is 3.56 . The predicted value of 2.24 was too high as the negative value of the residual results showed that the predicted results were too high. A Standard deviation less than the value of 1 showed that all the statistical data sets are all close to the mean value of the data set. All the standard deviation values of $0.6550,0.9970$ and 0.2228 were all less than, hence had low variances $(\mathrm{CV}<1$, low variance). This also showed that all the responses for sanitary landfill rated sanitary landfill very high. This study found that sanitary landfilling waste disposal method had a significant impact on the environment as it was preferred as a good alternative for wasted disposal by: scientist, chemist, manufacturers, individuals and environmental management wasted disposal officers. This finding agrees with the studies of Costa (2019), Chen (2018), Mohammed (2012) and Abu Rukah et al (2010). From the study, it can be concluded that operations of sanitary landfill deeply affects the environment positively, its operations when carried out with standards, control pollution in the environment, promotes sustainable manufacturing waste disposal methods such as recycle, reuses, reduce and remanufacture hence, sustainable manufacturing systems is encouraged. A higher patronage of sanitary landfills increased waste management and decreased pollution, as the gas (methane) was converted to methane gas to generate electricity. On the basis of this, there is need to: (1). Ensure that no hazardous wastes from industries are dumped into sanitary landfills but only municipal waste that is well sorted. (2). Establish sanitary landfills with good access roads, well-constructed perimeter fencing and availability of weighing bridge to eradicate open burning in sanitary landfills owned by government. (3). Increase awareness level in sorting of waste as regards recycling, reuse, remanufacture and sanitary landfilling.

Conclusion: Increase in sanitary landfilling activities resulted in a drastic decrease in environmental pollution. All sanitary landfills should operate to standard to protect the environment, control pollution and contain waste disposal. From the investigations in this research, the manufacturing sector fully supported the establishment of more sanitary landfills for industrial waste disposal. Sanitary landfill waste disposal method when operated under standard conditions, will help to protect the environment and control pollution in Edo state. In conclusion, this research paper accomplished the research objective and hypothesis in the area of waste disposal. However, it will set a base for further studies in Pollution control and waste management.

\section{REFERENCES}

Costa, AM.; De Souza, RG; Campos, JC (2019). Landfill Leachate treatment in Brazil- An overview. Int. J. Environ. Manage. 232: 110-116

Fei, F; Wen, Z; Declercq, D (2019). Spatial-temporal estimation of landfill gas energy potential. A case study of China. J. Renew. Sust. Energy. Review. 103: $217-226$

Chen, YCH (2018). Evaluating Greenhouse gas emission and Industrial solid waste using waste to-energy. Int. J. of Cleaner Prod. 192. 262-269

Mohammad, A; Kenneth, MP (2012). Environmental impact of municipal solid waste landfills in semiarid climates. Caste study: Jordan. Open. Waste. Manage. J. 5: 28-39

Adewale, MT (2011). Composting as a sustainable waste management technique in developing countries. Int. J. Environ. Sci. Tech. 4: 93-102

Awomeso, JA; Taiwo, AW; Gbadebo, AM; Arimoro, AA (2010). Waste disposal and pollution management in urban areas: A workable remedy for the environment in developing countries. Am. J. Environ. Sci. 6:26-32

Orebiyi, EO; Awomeso, JA; Idowu, OA; Martins, OO; Taiwo, AM (2010). Assessment of pollution hazards in shallow well water in Abeokuta and environs, South west Nigeria. Am. J. Environ. Sci. 6: $50-56$.

Abu Rukah, Y; Marc, A; Ghiefat, H (2010). Hydrogeological data evaluation and solid waste management at Al-Akeeder Landfill site, Jordan: Assessing pollution risks. Int. J. Ecol. Environ. Sci. 36: 175-186

Egun, NK (2010). Assessment of level of environmental consciousness in Delta stateNigeria. Int. J. Environ. Sci. 5 (4): 634-637.

Seo, SA; Aramaki, T; Hwang, Y; Hanaki, K (2004). Environmental impact of solid waste treatment methods in Korea. Int. J. Environ. Eng. 130: 8189

Senkoro, H (2013). Solid waste in Africa: A WHO/AFRO perspective CWG workshop: solid 
waste collection that benefits the urban poor. Dares Salaam, Tanzania.

UNEP (2002). International source book on environmentally sound technologies for municipal solid waste management. (ICTC) technical publication, USA.

Holze, I (2019). Contaminant patterns in soils form landfill mining. Int. J. Waste. Mange. 83: 151160
Magdalena, D.V (2019). Landfill impacts on the environment- Review. Int. J. Waste. Manage. Environ. Rem. 9 (10): 431-441

Robertson, S; Douglas, P; Jarvis, D (2019). Bioaerosol exposure from composing facilities and health outcomes in workers and in the community. A systematic review update. Int. J. Hygiene. Environ. Health. 222: 364-386. 